\title{
Marine Ecosystem Connections: essential indicators of healthy, productive and biologically diverse seas
}

\author{
Suzanne J. Painting • Rodney M. Forster
}

Published online: 22 March 2013

(C) Crown Copyright 2013

Welcome to this Special Issue of Biogeochemistry, which highlights the key research findings from a fiveyear study entitled "Marine Ecosystem Connections: essential indicators of healthy, productive and biologically diverse seas". The overall aims of the programme were to improve our scientific understanding of the functioning of shelf seas, develop tools for predicting the impact of human activity on ecosystem structure and function, and contribute to the development of indicators for assessments of ecosystem health and environmental status. Key to these studies was the focus on linkages between benthic and pelagic food webs, in response to environmental drivers (Fig. 1), and an underpinning requirement to link the research on biogeochemical cycling to the development of tools and approaches for improved management of marine resources.

Around the world, in countries such as Australia, Canada, China, North America and South Africa, recent policy and legislative drivers require integrated, ecosystem-based assessments of the impacts of human activities (see Borja et al. 2008; Elliott 2011). In Europe, for example, the Marine Strategy Framework Directive (MSFD, CEC 2008) aims to achieve Good Environmental Status (GES) in all water bodies by

S. J. Painting $(\bowtie) \cdot$ R. M. Forster

Centre for Environment, Fisheries and Aquaculture

Science (Cefas), Pakefield Road, Lowestoft, Suffolk

NR33 OHT, UK

e-mail: suzanne.painting@cefas.co.uk
2020, and requires that "the structure, functions and processes of the constituent marine ecosystems" allow them "to function fully and to maintain their resilience to human-induced environmental change", taking account of "associated physiographic, geographic, geological and climatic factors". A number of coastal and marine regions, including the North Sea, have therefore become the focus of ongoing research on ecosystem structure and function, and the development of indicators for assessing environmental status (see COM 2010).

Studies carried out during 'Marine Ecosystem Connections' (MEC) are part of this effort. A combined fieldwork and modelling approach was used to quantify carbon and nitrogen fluxes through pelagic and benthic food webs in the temperate North Sea, to predict the impacts of climate change and demersal trawling on these fluxes (van der Molen et al. 2012), and to select and evaluate indicators of ecosystem functioning in terms of their suitability for assessing and managing the impacts of climate change and demersal trawling (Painting et al. 2012). For the pelagic food web, only lower trophic levels (up to zooplankton) were considered, as they have fast turnover rates and are useful as early warning indicators of environmental change. For the benthic food web, the main functional groups of the faunal communities were considered. Coupled physical-biogeochemical models (GOTM-ERSEM-BFM) were developed to improve their suitability for temperate shelf seas (see van der Molen et al. 2012), e.g. through parameterisation to allow growth of diatoms 
Fig. 1 Key linkages driving ecosystem dynamics and biogeochemical cycles (previously published in Salihoglu et al. 2013): with climate forcing, hydrography, benthic food webs, pelagic food webs and higher trophic levels all inter-linked. Climate is influenced by factors such as the North Atlantic Oscillation (NAO), the Gulf Stream Index (GSI), and atmospheric temperatures

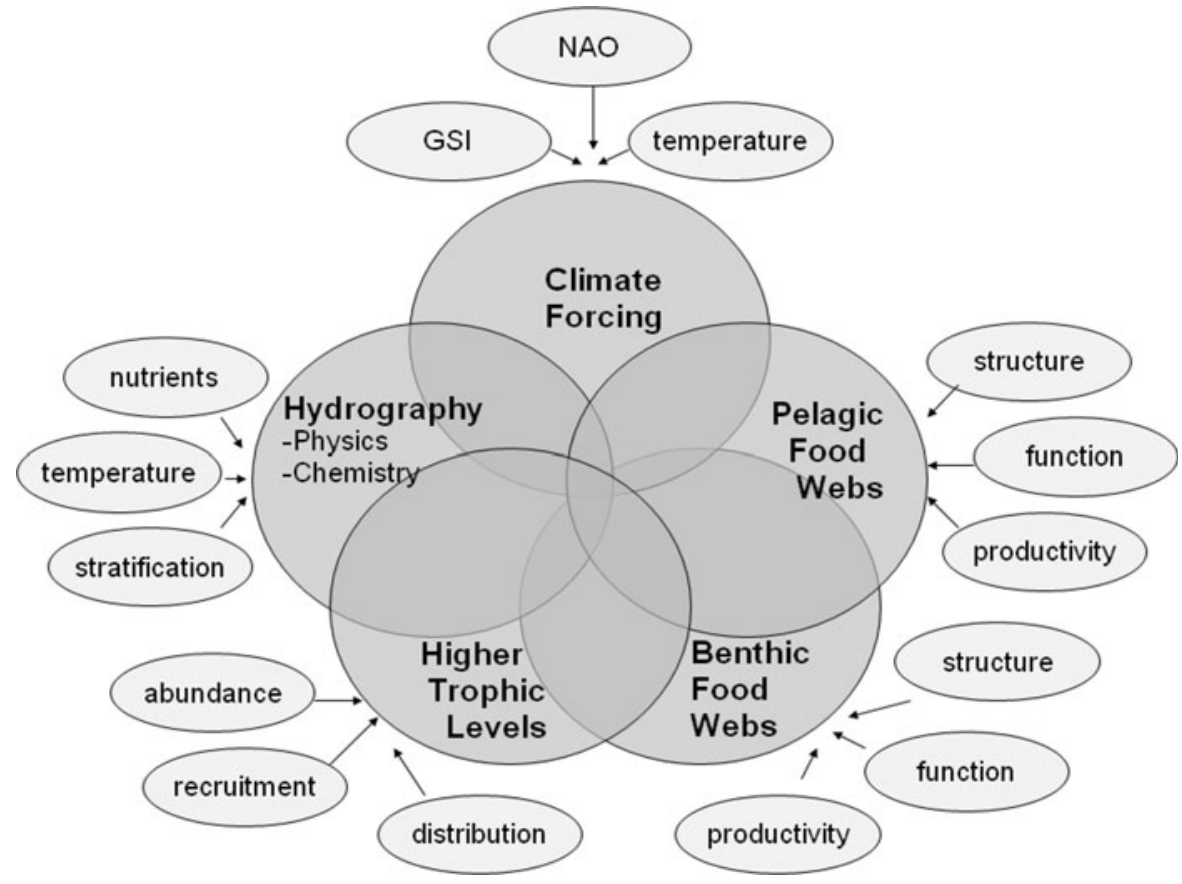

during the spring phytoplankton bloom, enhanced diatom excretion of transparent exopolymer particles (TEP) under nutrient stress, the formation of TEPdiatom macro-aggregates to enhance rates of sinking to the seabed and associated fauna, and to improve simulation of the underwater light climate.

Fieldwork was carried out largely at three study sites (Fig. 2) representing different hydrodynamicseabed types (also referred to as ecohydrodynamic types) likely to affect the biogeochemical cycling of carbon and nutrients in each region (see Tett et al. 2007). In situ semi-autonomous instruments were deployed at each site to obtain continuous highfrequency measurements of key biogeochemical parameters such as temperature, chlorophyll fluorescence, optical backscatter, photosynthetically active radiation, inorganic and organic dissolved nutrients, and dissolved oxygen over annual cycles (see Greenwood et al. 2010; Capuzzo et al. 2012; Johnson et al. 2012). Seasonal cruises allowed more in-depth studies of these key parameters, as well as of sediment resuspension (Couceiro et al. 2012), hypoxia and nutrient cycling (Neubacher et al. 2011, 2012), structure and functioning of seabed communities (Birchenough 2012a, b), and the trophic dynamics of zooplankton (Kürten et al. 2011) and benthic and pelagic functional feeding groups (Kürten et al. 2012). Broader sampling contributed further understanding of particulate nutrient sources in coastal waters (Bristow et al. 2012), temporal and/or spatial variability in primary production (Fernand et al. (2013); van Leeuwen et al. 2012), pelagic microbial communities (Brandsma et al. 2012) and oxygen depletion in bottom waters (Queste et al. 2012).

\section{Features of the main study sites}

The three sites selected for detailed study in the North Sea (2007 and 2008, Fig. 2; see papers in this Issue, and references therein, e.g. Bristow et al. 2012; Capuzzo et al. 2012; Kürten et al. 2011) were representative of larger regions with similar water column and seabed characteristics (see Fig. 3). The distribution of these regions was derived using $\mathrm{k}$-means clustering based on water depth, percentage of silt and clay in the seabed sediment and degree of water column stratification (van der Molen et al. 2012). The site in the southern Bight (SB) is characterised by a shallow (ca $30 \mathrm{~m}$ ), well-mixed water column and relatively coarse sediments with a deep oxic layer $(>10 \mathrm{~cm})$. The site is located in the East Anglian Turbidity Plume, which moves eastwards across the southern Bight towards the German Bight, and is subjected to strong tides and waves, which advect and re-suspend sediments. Physical processes 
Fig. 2 Location of primary study sites (white circles) in each of three eco-

hydrodynamic regions in the southern and central North Sea (see van der Molen et al. 2012). Blue the region represented by a site north of the Dogger Bank (North Dogger, ND). Brown the region represented by a site in the Oyster Grounds (OG). Green the region represented by a site in the southern Bight (SB)

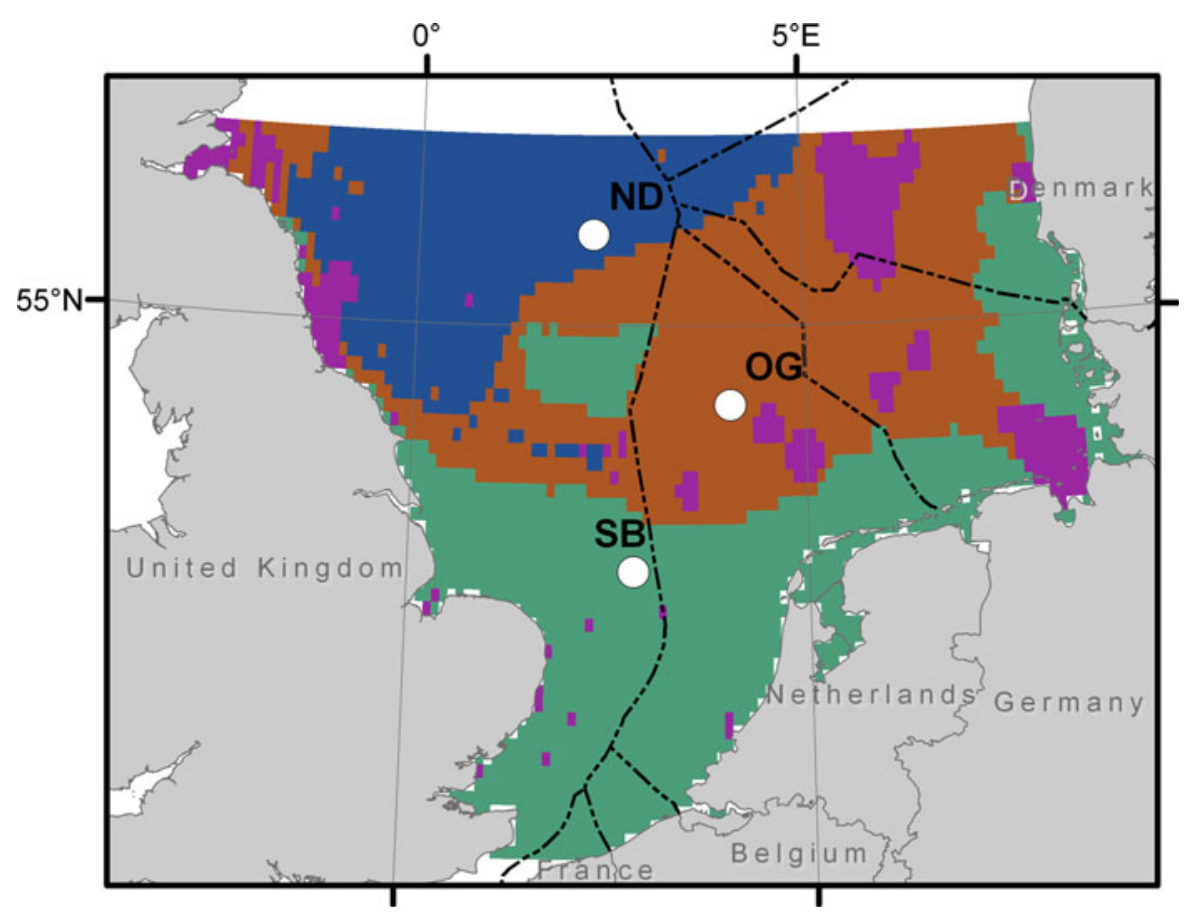

(2012a, b). Details of the under-water light regime at the three sites are given by Capuzzo et al. (2012), and seasonal changes in trophodynamics of zooplankton and benthic and pelagic functional groups are described by Kürten et al. $(2011,2012)$.

Key strengths

The overall aims of the MEC study and the range of studies undertaken were very broad. Nonetheless, the focus on ecohydrodynamic types, a combined fieldwork and modelling approach, and linkages between benthic and pelagic food webs, and between research and the development of management tools, were key strengths of the programme. As were the combined use of in situ instruments and seasonal cruises, and traditional and novel methods, during the field campaign.

Certainly, the combined fieldwork-modelling approach adopted during MEC was invaluable for describing ecosystem structure and quantifying carbon and nutrient fluxes and budgets at the main study sites, predicting likely impacts of climate change and demersal trawling (van der Molen et al. 2012), and contributing to the development of indicators of ecosystem functioning (Painting et al. 2012).

Model confirmation and validation (van der Molen et al. 2012; van Leeuwen et al. 2012) indicated that the 


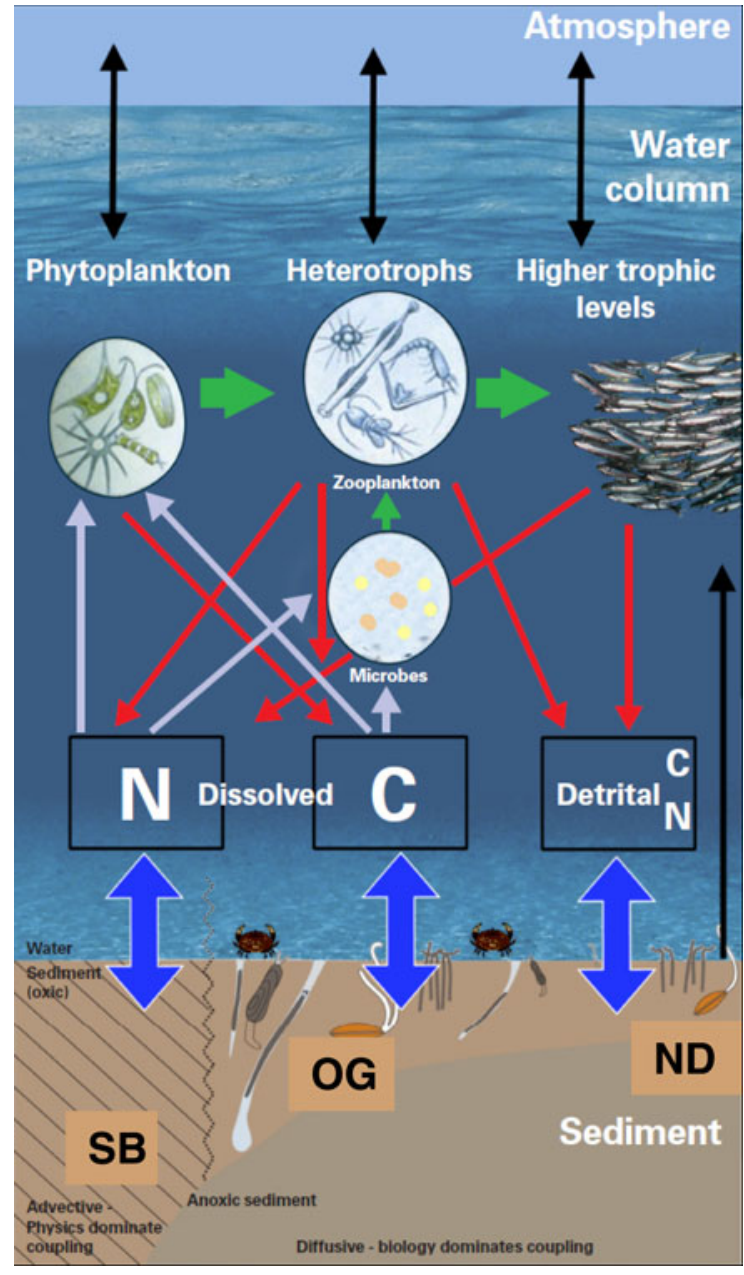

Fig. 3 Conceptual model of the main carbon (C) and nitrogen (N) flows between pelagic and benthic food webs (from Painting et al. 2012). Main trophic pathways are from phytoplankton to heterotrophs to higher trophic levels, and from benthic fauna to fish. Nutrients are available from dissolved and detrital pools, and atmospheric inputs. Sediment communities are influenced by sediment types (coarse through muddy) and the depth of the oxic layer. The lower half of the diagram represents a gradient in sediment types across the study sites. $S B$ site in the southern Bight, $O G$ Oyster Grounds, $N D$ site north of the Dogger Bank

coupled physical-biological models used during MEC provided realistic simulation of many parameters in the models, and the coupling between processes in the water column and the seabed. Model confirmation also indicated where improvements are needed in both the observations and the models to improve our confidence in the model results and the evaluation of indicators (van der Molen et al. 2012; Painting et al. 2012).
Key challenges

Studies carried out during MEC were based largely on a conceptual model of the main carbon and nitrogen flows through coupled benthic and pelagic food webs (Fig. 3), and key functional groups in both domains. A number of challenges were encountered during the project, including: the implementation of simultaneous intensive multi-disciplinary research during the primary field campaign; the availability of sufficient data for the analysis and interpretation of key carbon and nitrogen flows, and for validation and confirmation of numerical models capturing these flows; integration of biogeochemical fluxes through the dissolved carbon and nutrient pools (e.g. Johnson et al. 2012) with more traditional and/or innovative food web studies (e.g. Bolam et al. 2010; Kürten et al. 2011, 2012); and model developments required to improve simulations of trophic dynamics and benthicpelagic coupling in the temperate North Sea. Many of these challenges are not unique to MEC and are discussed in greater detail by Salihoglu et al. (2013, see Fig. 4), who support this approach on local and regional scales for improved understanding of biogeochemical cycling and management of the marine environment. Certainly, the key challenge for science is to provide an adequate understanding of the structure and functioning of the marine environment so that future pressures such as anthropogenic climate change and changes in human activities can be put into context. This requires the development of methods to describe the structure and functioning of ecosystems and mechanisms to predict and minimise the impacts of human activities to avoid undesirable disturbances (Tett et al. 2007). Approaches to all future ecosystem studies will need to focus on key linkages between ecosystem compartments (Fig. 1), and to include field measurements and ecosystem models, such as those described in Salihoglu et al. (2013). These authors also recommend comparative studies in order to identify similarities and differences across ecosystems. For all approaches, key issues include establishing general requirements of the study, particularly in terms of field measurements and the level of detail required. The benefits of complex versus simple approaches (such as that used here) are a source of debate. While simple approaches with clear assumptions may be more powerful, species-based approached are also needed (see Salihoglu et al. 2013 and references therein). 
Fig. 4 Conceptual diagram of integrated studies on biogeochemical cycling and ecosystem structure and functioning (from Salihoglu et al. 2013). Flow charts indicate key interactions; bottom panels indicate approaches to enhance understanding and usefulness of integrated studies to resource managers

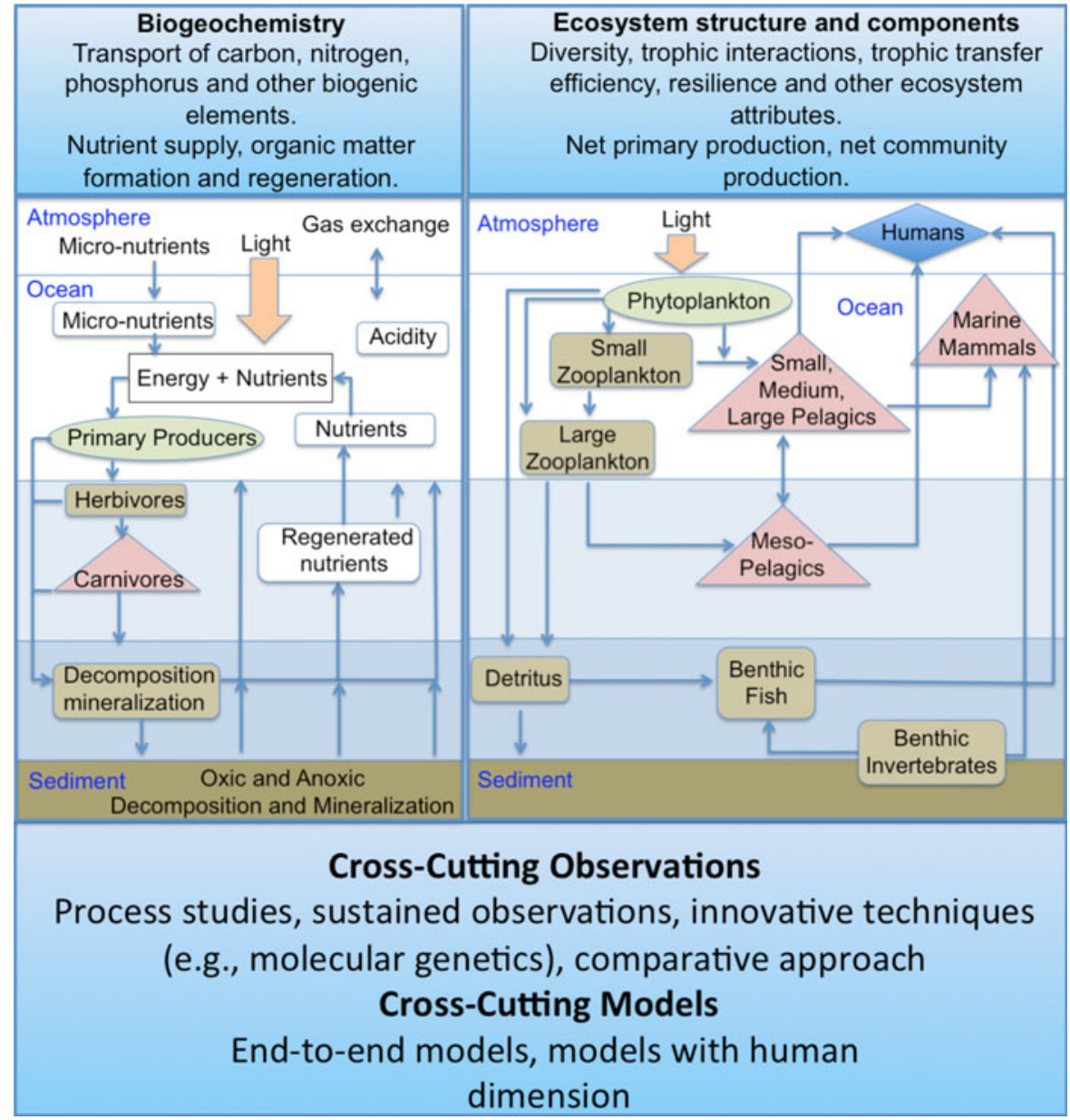

Chief of Biogeochemistry, Katja Lajtha, for the opportunity to publish these papers as a valuable collection, and to Ayrene Dialogo, Nandhini Kesavan and LeAnn Smiles in the Springer Editorial Office for their support during this process. We also acknowledge and thank the UK Department for Environment, Food and Rural Affairs (Defra, Cefas Contract ME3205) for core funding, and the many Universities, Institutes and other organisations who supported collaborators, supervisors and studentships, and are acknowledged in full in their publications and/or dissertations. We are very grateful to Defra and other policy-friendly colleagues for constant feedback on the direction and relevance of $M E C$.

\section{References}

Birchenough SNR, Bolam SG, Parker ER (2012a) SPI-ing on the seafloor: characterising benthic systems with traditional and in situ observations. Biogeochemistry. doi: 10.1007/s10533-012-9811-3

Birchenough SNR, Parker ER, McManus E, Barry J (2012b) Combining bioturbation and redox metrics: potential tools up much of their time to review the manuscripts and provide constructive comments. We are very grateful to the Editor-in- 
for assessing seabed function. Ecol Indic 12:8-16. doi: 10.1016/j.ecolind.2011.03.015

Bolam SG, Barrio-Frojan CRS, Eggleton JD (2010) Macrofaunal production along the UK continental shelf. J Sea Res 64:166-179

Borja Á, Bricker SB, Dauer DM, Demetriades NT, Ferreira JG, Forbes AT, Hutchings P, Jia X, Kenchingotn R, Marques JC, Zhu C (2008) Overview of integrative tools and methods in asssessing ecological integrity in estuarine and coastal systems worldwide. Mar Pollut Bull 56:1519-1537

Brandsma J, Martinez JM, Slagter H, Evans C, Brussaard C (2012) Summer distribution of microorganisms in the North Sea. Biogeochemistry. doi:10.1007/s10533-0129783-3

Bristow LA, Jickells T, Weston K, Marca-Bell A, Parker R, Andrews J (2012) Tracing estuarine organic matter sources into the southern North Sea using $\mathrm{C}$ and $\mathrm{N}$ isotopic signatures. Biogeochemistry. doi:10.1007/s10533-012-9758-4

Capuzzo E, Painting SJ, Forster RM, Greenwood N, Stephens DT, Mikkelsen OA (2012) Variability in the sub-surface light climate at ecohydrodynamically distinct sites in the North Sea. Biogeochemistry. doi:10.1007/s10533-012-9772-6

CEC (2008) Directive 2008/56/EC of the European Parliament and of the Council of 17 June 2008 establishing a framework for community action in the field of marine environmental policy (Marine Strategy Framework Directive)

COM (2010) Commission Decision of 1 September 2010 on criteria and methodological standards on good environmental status of marine waters (2010/477/EU)

Couceiro F, Fones GR, Thompson CEL, Statham PJ, Sivyer DB, Parker R, Kelly-Gerreyn BA, Amos CL (2012) Impact of resuspension of cohesive sediments at the Oyster Grounds (North Sea) on nutrient exchange across the sediment-water interface. Biogeochemistry. doi:10.1007/s10533-0129710-7

Elliott M (2011) Marine science and management means tackling exogenic unmanaged pressures and endogenic managed pressures: a numbered guide. Mar Pollut Bull 62: 651-655

Fernand L, Weston K, Morris T, Greenwood N, Brown J, Jickells T (2013) The contribution of the deep chlorophyll maximum to primary production in a seasonally stratified shelf sea, the North Sea. Biogeochemistry. doi: 10.1007/s10533-013-9831-7

Greenwood N, Parker ER, Fernand L, Sivyer DB, Weston K, Painting SJ, Kröger S, Forster RM, Lees HE, Mills DK, Laane RWPM (2010) Detection of low bottom water oxygen concentrations in the North Sea; implications for monitoring and assessment of ecosystem health. Biogeosciences 7:1357-1373

Johnson MT, Greenwood N, Sivyer DB, Thomson M, Reeve A, Weston K, Jickells TD (2012) Characterising the seasonal cycle of dissolved organic nitrogen using Cefas SmartBuoy high-resolution time-series samples from the Southern North Sea. Biogeochemistry. doi:10.1007/s10533-012-9738-8

Kürten B, Painting SJ, Struck U, Polunin NVC, Middelburg JJ (2011) Tracking seasonal changes in North Sea zooplankton trophic dynamics using stable isotope. Biogeochemistry. doi:10.1007/s10533-011-9630-y

Kürten B, Frutos I, Struck U, Painting SJ, Polunin NVC, Middelburg JJ (2012) Trophodynamics and functional feeding groups of North Sea fauna: a combined stable isotope and fatty acid approach. Biogeochemistry. doi:10.1007/s10533012-9701-8

Neubacher EC, Parker RE, Trimmer M (2011) Short-term hypoxia alters the balance of the nitrogen cycle in coastal sediments. Limnol Oceanogr 56:651-665

Neubacher E, Parker R, Trimmer M (2012) The potential effect of sustained hypoxia on nitrogen cycling in sediment from the southern North Sea: a mesocosm experiment. Biogeochemistry. doi:10.1007/s10533-012-9749-5

Painting SJ, van der Molen J, Parker R, Coughlan C, Birchenough S, Bolam S, Aldridge J, Forster R, Greenwood N (2012) Development of indicators of ecosystem functioning in a temperate shelf sea: a combined fieldwork and modelling approach. Biogeochemistry. doi:10.1007/s10533012-9774-4

Queste BY, Fernand L, Jickells TD, Heywood KJ (2012) Spatial extent and historical context of North Sea oxygen depletion in August 2010. Biogeochemistry. doi:10.007/s10533-0129729-9

Salihoglu B, Neuer S, Painting S, Murtugudde R, Hofmann EE, Steele JH, Hood RR, Legendre L, Lomas MW, Wiggert JD, Ito S, Lachkar Z, Hunt G, Drinkwater KF, Sabine CL (2013) Bridging marine ecosystem and biogeochemistry research: lessons and recommendations from comparative studies. J Mar Syst 109-110:161-175. doi:10.1016/j.jmarsys.2012. 07.005

Tett P, Gowen R, Mills D, Fernandes T, Gilpin L, Huxham M, Kennington K, Read P, Service M, Wilkinson M, Malcolm S (2007) Defining and detecting undesirable disturbance in the context of marine eutrophication. Mar Pollut Bull 55:282-297

van der Molen J, Aldridge J, Coughlan C, Parker ER, Stephens D, Ruardij P (2012) Modelling marine ecosystem response to climate change and trawling in the North Sea. Biogeochemistry. doi:10.1007/s10533-012-9763-7

van Leeuwen SM, van der Molen J, Ruardij P, Fernand L, Jickells $\mathrm{T}$ (2012) Modelling the contribution of deep chlorophyll maxima to annual primary production in the North Sea. Biogeochemistry. doi:10.1007/s10533-012-9704-5

\section{Related publications}

Kenny AJ, Skjoldal AR, Engelhard GH, Kershaw PJ, Reid JB (2009) An integrated approach for assessing the relative significance of human pressures and environmental forcing on the status of Large Marine Ecosystems. Prog Oceanogr 81:132-148

Sapp M, Parker R, Teal LR, Schratzberger M (2010) Advancing the understanding of biogeography-diversity relationships of benthic microorganisms in the North Sea. FEMS Microbiol Ecol 74:410-429

Schratzberger M, Forster RM, Goodsir F, Jennings S (2008) Nematode community dynamics over an annual production cycle in the central North Sea. Mar Environ Res 66(5): 508-519

Soltwedel T, Lansard B, Gilbert F, Hasemann C, Bell E, Sablotny B, Eagle M, Kershaw P, Rabouille C (2008) An integrated sediment disturber (ISD) to study the impact of 
repeated physical perturbations on the sediment geochemistry and related effects on the small benthic biota. Limnol Oceanogr Methods 6:307-318

Suratman S, Jickells T, Weston K, Fernand L (2008) Seasonal variability in inorganic and organic nitrogen in the North Sea. Hydrobiologia 610:83-98

Suratman S, Weston K, Jickells T, Fernand L (2009) Spatial and seasonal changes of dissolved and particulate organic $\mathrm{C}$ in the North Sea. Hydrobiologia 628:13-25

Suratman S, Weston K, Greenwood N, Sivyer DB, Pearce DJ, Jickells T (2010) High frequency measurements of dissolved inorganic and organic nutrients using instrumented moorings in the southern and central North Sea. Estuar Coast Shelf Sci 87:631-639. doi:10.1016/j.ecss.2010.03. 001

Teal LR, Bulling MT, Parker ER, Solan M (2008) Global patterns of bioturbation intensity and mixed depth of marine soft sediments. J Mar Biol 2(3):207-218

Teal LR, Parker ER, Fones GF, Solan M (2009) Simultaneous determination of vertical transitions of colour, porewater metals and visualisation of infaunal activity in marine sediments. Limnol Oceanogr 54(5):1801-1810

Van Hoey G, Borja A, Birchenough SNR, Degraer S, Fleischer D, Magni P, Muxika I, Reiss H, Rumohr H, Schröder A, Zettler M (2010) The use of benthic indicators in Europe: from the Water Framework Directive to the Marine Strategy Framework Directive. Mar Pollut Bull 60(12): 2187-2196

\section{Theses}

Benson K (2008) The effects of trawling induced resuspension on phytoplankton dynamics in the North Sea. MSc NOC, Southampton
Beswick CE (2007) Benthic foraminifera in the North Sea as indicators of ecosystem connectivity and climate variability. MSc dissertation, University of Southampton, $v i+69$ pp

Bristow LA (2009) Tracing nitrogen flows across the southern North Sea: a stable isotope approach. $\mathrm{PhD}$ thesis UEA, Norwich, Xv +200 pp

Forryan A (2007) Modelling ecosystems, carbon flow and fishing impacts in the North Sea. MSc thesis NOC, Southampton

Jones C (2008) Changes in sediment nutrient fluxes driven by seabed disturbance in the North Sea: a GIS approach. MSc thesis NOC, Southampton

Cubbin A (2009) Trace metals in North Sea sediments. MSc thesis NOC, Southampton

Kürten B (2010) An end-to-end study of spatial differences in North Sea food webs. PhD dissertation, University of Newcastle upon Tyne, $x v i+312 \mathrm{pp}$

Lukes N (2009) Dissolved phosphorus in North Sea sediments. MSc thesis NOC, Southampton

Morris TR (2009) The importance of the deep chlorophyll maxima to primary production in the North Sea. MSc dissertation, University of Southampton, $94 \mathrm{pp}$

Neubacher E (2009) Oxygen and nitrogen cycling in sediments of the North Sea. PhD dissertation, Queen Mary College, University of London, $183 \mathrm{pp}$

Saverymuttu K (2008) Application of Cefas SmartBuoy data to modeling vertical structure and primary production in the North Sea. M.Sc dissertation, University of Southampton, $\mathrm{v}+108 \mathrm{pp}$

Teal LR (2009) The influence of infaunal bioturbation on ecosystem processes in the sediment mixed layer. $\mathrm{PhD}$ dissertation, University of Aberdeen, ix $+126 \mathrm{pp}$ 